\title{
PENGARUH PEMBERIAN MPASI PABRIKAN DAN MPASI LOKAL TERHADAP STATUS GIZI BAYI
}

\author{
Ani Triana, Liva Maita \\ STIKes Hang Tuah Pekanbaru Prodi Kebidanan \\ livamaita@gmail.com
}

\begin{abstract}
Nutrition improvement programs aimed at increasing the amount and quality of MP-ASI have been carried out, including the provision of MP-ASI for infants and children aged 6-24 months from poor families. In general, there are two types of MP-ASI, which is the result of factory processing or what is known as the manufacturer's MP-ASI and which is processed at home or referred to as local MP-ASI. This study aims to determine the effect of manufacturing MPASI and local MPASI on the nutritional status of infants in the working area of Sidomulyo Health Center. This research was conducted through a quasy experiment research design with a series of time (time series design) that is without using the control group as a comparison. The population is babies aged 6-12 months with a sample of 15 people in the group who were given MP-ASI Manufacturing and 15 groups who were given Local MP-ASI. The results of the study there is no influence of Manufacturing MPASI and Local MPASI on nutritional status with pvalue $=$ 0.548 . The need for counseling about nutritional needs, training in food processing and weighing and measuring baby's height regularly
\end{abstract}

Keywords: Manufacturing MP-ASI, Local MP-ASI, Nutritional Status

\begin{abstract}
Abstrak : Program perbaikan gizi yang bertujuan meningkatkan jumlah dan mutu MPASI, selama ini telah dilakukan, diantaranya pemberian MP-ASI kepada bayi dan anak usia 6 - 24 bulan dari keluarga miskin. Secara umum terdapat dua jenis MP-ASI yaitu hasil pengolahan pabrik atau disebut dengan MP-ASI pabrikan dan yang diolah di rumah tangga atau disebut dengan MP-ASI lokal. Penelitian ini bertujuan untuk mengetahui pengaruh Pemberian MPASI pabrikan dan MPASI Lokal terhadap Status Gizi Bayi di Wilayah Kerja Puskesmas Sidomulyo. Penelitian ini dilakukan melalui desain penelitian quasi experiment dengan rangkaian sewaktu (time series design) yaitu tanpa menggunakan kelompok kontrol sebagai pembanding. Populasi adalah bayi yang berusia 6-12 bulan dengan jumlah sampel 15 orang kelompok yang diberi MP-ASI Pabrikan dan 15 orang kelompok yang diberi MP-ASI Lokal. Hasil penelitian pengaruh Pemberian MPASI Pabrikan dan MPASI Lokal terhadap status gizi dengan pvalue $=0,548$. Perlunya Konseling tentang kebutuhan gizi, latihan pengolahan bahan makanan serta penimbangan berat badan dan pengukuran tinggi badan bayi secara teratur
\end{abstract}

Kata Kunci : MP-ASI Pabrikan, MP-ASI Lokal, Status gizi

WHO pada tahun 2002 melaporkan bahwa

$54 \%$ kematian balita di seluruh dunia disebabkan secara langsung maupun tidak langsung oleh gizi kurang dan gizi buruk. Angka ini belum banyak berubah pada data WHO tahun 2011, yang melaporkan bahwa $45 \%$ kematian balita di seluruh dunia terkait dengan malnutrisi (WHO, 2013 dalam Kemenkes RI, 2015). Selanjutnya, data-data WHO memperlihatkan bahwa penurunan berat badan mulai terjadi pada usia 4-6 bulan yang dikenal sebagai periode penyapihan. Hal ini juga diperkuat dengan temuan bahwa dua per tiga balita yang meninggal tersebut mempunyai pola makan bayi yang salah antara lain tidak 
mendapatkan air susu ibu (ASI) eksklusif serta mendapat makanan pendamping ASI (MPASI) yang terlalu dini atau terlambat disertai komposisi zat gizi yang tidak lengkap, tidak seimbang dan tidak higienis (WHO, 2003 dalam Kemenkes RI, 2015).

Program perbaikan gizi yang bertujuan meningkatkan jumlah dan mutu MP-ASI, selama ini telah dilakukan, diantaranya pemberian MP-ASI kepada bayi dan anak usia $6-24$ bulan dari keluarga miskin. Secara umum terdapat dua jenis MP-ASI yaitu hasil pengolahan pabrik atau disebut dengan MP-ASI pabrikan dan yang diolah di rumah tangga atau disebut dengan MP-ASI lokal. Mengingat pentingnya aspek sosial budaya dan aspek pemberdayaan masyarakat dalam kegiatan pemberian MP-ASI maka MP-ASI yang akan diberikan pada tahun 2006 yaitu MPASI lokal atau disebut juga " MP-ASI dapur ibu "(Kemenkes RI, 2015).

Menurut Nestel, dkk (2003) dalam (Pratiwi, 2010) akan tetapi, pemberian ASI lokal di beberapa negara berkembang belum dapat memberikan sumber energi dan mikronutrien yang sesuai dengan kebutuhan sehari-hari. Namun selama dua dekade terakhir, pemilihan MP-ASI pabrikan terutama dalam bentuk instan menjadi pilihan yang utama bagi para ibu dari berbagai tingkat sosio-ekonomi. Umumnya, pemilihan MP- ASI pabrikan disebabkan cara pemberian yang lebih mudah, praktis, dan mengandung jumlah zat gizi yang sesuai dengan kebutuhan anak sesuai dengan usianya.

Hasil wawancara pada 10 orang ibu yang mempunyai bayi usia 6-11 bulan yang telah mendapatkan MP-ASI pabrikan dan lokal ditemukan bahwa 7 orang bayi dengan berat badan yang tidak stabil (naik turun), dan 3 ibu lainnya mengatakan pertumbuhan (berat badan) bayinya naik setiap bulannya. Saat ditanyakan frekuensi pemberian MP-ASI yang tepat, 6 dari 7 orang ibu dari bayi yang pertumbuhannya tidak stabil menyatakan frekuensi pemberian MP-ASI baik pabrikan maupun Lokal pada bayinya tidak teratur dengan alasan ibu sedang bekerja, 1 diantaranya mengatakan bahwa bayi saat itu sedang sakit, sehingga bayi menjadi rewel dan tidak mau makan. Dari hasil survei awal yang dilakukan oleh peneliti yaitu 30 orang ibu yang mempunyai bayi usia 6-11 bulan di wilayah kerja Puskesmas Sidomulyo yang ditemui oleh peneliti dan dilakukan wawancara tentang pemberian ASI dan MP-ASI pabrikan dan lokal terhadap pertumbuhan, dari 30 bayi yang ditemui peneliti terdapat $16(53,33 \%)$ bayi yang tidak sesuai KBM dan 14 (36,66\%) yang sesuai KBM. Dan untuk kecukupan energi dan protein terdapat $18(60 \%)$ yang tidak cukup energi dan protein, dan $12(20 \%)$ yang cukup energi dan protein. Oleh karena itu peneliti tertarik meneliti dengan judul 
Pengaruh Pemberian MPASI pabrikan dan MPASI lokal terhadap Status Gizi Bayi di Wilayah Kerja Puskesmas Sidomulyo

\section{BAHAN DAN CARA KERJA}

Jenis penelitan analik kuantitatif dengan desain penelitian quasy experiment dengan rangkaian sewaktu (time series design). Populasi adalah seluruh bayi yang berusia $6-12$ bulan yang berada di Wilayah Kerja Puskesmas Sidomulyo Kota Pekanbaru. Sampel penelitian ini adalah sebagian bayi yang berusia 6-12 bulan yang berjumlah 30 orang. Teknik pengambilan sampel adalah teknik sampling jenuh dengan kriteria sample bayi sehat dengan BB bayi saat lahir cukup serta berusia 6-12 bulan.

Variabel independen dalam penelitian ini yaitu MP-ASI pabrikan dan MP-ASI lokal sedangkan variable dependen yaitu status gizi bayi. Metode pengumpulan data dengan cara wawancara dan observasi status gizi bayi melaui penimbangan berat badan dibandingkan dengan umur. Analisa data univariat dan Bivariat dengan menggunakan uji T-independen.

\section{HASIL}

Hasil penelitian yang didapatkan yaitu terdapat 15 orang bayi yang berusia 6-12 bulan dengan MP-ASI pabrikan dan 15 orang bayi yang berusia 6-12 bulan dengan MP-ASI lokal.
Tabel 1 Distribusi Rata-rata Status Gizi Menurut Pemberian MPASI Lokal dan Pabrikan

\begin{tabular}{lccccc}
\hline MPASI & Mean & SD & SE & pvalue & N \\
& & & & & \\
\hline Pabrikan & 1,07 & 0,961 & 0,248 & 0,548 & 15 \\
Lokal & 0,87 & 0,834 & 0,215 & & 15
\end{tabular}

Rata-rata status gizi bayi yang diberikan MPASI Pabrikan yaitu 1,07 dengan standar deviasi 0,961, sedangkan status gizi bayi yang diberikan MPASI Lokal rata-rata adalah 0,87 dengan standar deviasi 0,834. Hasil Uji statistik didapatkan pvalue 0,548 (> 0,05) berarti tidak ada pengaruh Pemberian MPASI Pabrikan dan MPASI Lokal terhadap status gizi di Wilayah Kerja Puskesmas Sidomulyo Kota Pekanbaru Tahun 2017.

\section{PEMBAHASAN}

Pada penelitian ini hasil uji statistik didapatkan pvalue 0,548 berarti tidak ada pengaruh Pemberian MPASI Pabrikan dan MPASI Lokal terhadap status gizi di Wilayah Kerja Puskesmas Sidomulyo Kota Pekanbaru Tahun 2017. Penelitian ini sejalan dengan penelitian Lestari (2014) bahwa tidak ada hubungan yang bermakna antara jenis MP-ASI dengan status gizi pada anak $\mathrm{p}=0,456(\mathrm{p}>0,05)$. Hal ini menunjukkan antara MP-ASI pabrik dan MP-ASI home made atau buatan sendiri memiliki manfaat yang sama selagi diberikan dalam jumlah yang cukup dan 
relatif bermutu. Menurut Mangkat (2016) bahwa MP-ASI lokal yaitu kadar gizi yang tidak terukur secara jelas, Walaupun dalam KMS telah tercantum cara pembuatan MPASI yang bergizi baik akan tetapi terkadang ibu rumah tangga tidak terlalu memperhatikan hal tersebut sehingga nantinya konsumsi MP-ASI lokal tidak terukur secara jelas kadar gizinya dan dapat memengaruhi perkembangan anak karena ketidaksesuaian antara asupan gizi dan kebutuhan gizi yang dibutuhkan oleh anak.

Kelebihan pada MP-ASI pabrikan ialah kadar gizinya telah diukur oleh Departemen Kesehatan RI untuk disesuaikan terhadap kebutuhan gizi anakanak yang mengonsumsinya. Kadar kandungan gizi yang telah terukur tersebut secara langsung akan berpengaruh terhadap perkembangan anak oleh karena zat gizi makronutrien dan mikronutrien yang terkandung di dalamnya merupakan faktor yang berpengaruh pada maturitas otak dan pembentukan jaringan-jarinan tubuh di masa keemasan tumbuh kembang anak, yaitu usia 1-3 tahun.

\section{DAFTAR RUJUKAN}

Dahlan, M. (2009). Besar Sampel Dan Cara Pengambilan Sampel Dalam Penelitian Kedokteran Dan Kesehatan. Jakarta: Salemba Medika.

Depkes RI. (2006). Pedoman Umum Pemberian Makanan Pendamping Air Susu Ibu (MP-ASI) Lokal Tahun 2006. Jakarta.

Departemen Kesehatan RI, (2003). Pedoman Umum Pemberian Makanan Pendamping Air Susu Ibu (MP-ASI) Lokal. Jakata.
Pengolahan bahan makanan tidak memperhatikan kebutuhan gizi bayinya. Pada MPASI Lokal para ibu mengolah makanan bayi disamakan menu dengan apa yang dimakan keluarga, sedangkan MPASI Pabrikan jumlah takaran yang diberikan tidak sesuai dengan kebutuhan bayi sehingga status gizi bayi rata-rata kurang dan buruk.

\section{KESIMPULAN}

Hasil Uji statistik didapatkan pvalue 0,548 berarti tidak ada pengaruh Pemberian MPASI Pabrikan dan MPASI Lokal terhadap status gizi di Wilayah Kerja Puskesmas Sidomulyo Kota Pekanbaru Tahun 2017. Berdasarkan hasil penelitian dapat diberikan beberapa saran untuk ibu yaitu Perlunya Konseling tentang status gizi pada ibu yang memiliki bayi usia 6-12 bulan, Perlunya latihan pengolahan bahan makanan pendamping ASI yang baik dan benar, Perlunya penimbangan berat badan dan pengukuran tinggi badan secara teratur melalui kunjungan ke Posyandu tiap bulannya.

IDAI. (2015). Praktik Pemberian Makan Berbasis Bukti pada Bayi dan Batita di Indonesia untuk Mencegah Malnutris. JAKARTA: Unit Kerja Koordinasi Nutrisi dan Penyakit Metabolik Ikatan Dokter Anak Indonesia. , (2004). Sistem Kesehatan Nasional 2004. Jakata.

, (2006). Pedoman Umum Pemberian Makanan Pendamping Air Susu Ibu (MP-ASI). Jakata. 
(2009). Pedoman Umum Pemberian Makanan Pendamping Air Susu Ibu (MP-ASI). Jakata.

Kartika, L. (12 Maret 2012). Makanan Pendamping ASI.

http://www.ibudanbalita.com/diskusi/pernyat aan/77201/Makanan-Pendamping-ASI-MPASI- (Online), diakses 30 Januari 2016.

Kemenkes RI. (2014). Infodatin. Jakarta: Pusat Data dan Informasi Kememterian Kesehatan RI.

Kemenkes RI. (2015). Paket Konseling: Pemberian Makan bayi dan Anak. Jakarta.

Krisniatuti, D. (2008). Menyiapkan Makanan Pendamping ASI. Jakarta : Puspa Swara.

Lestari, MU., Lubis, G., dan Pertiwi, D. 2014. Hubungan Pemberian Makanan Pendamping Asi (MP-ASI) dengan Status Gizi Anak Usia 13 Tahun di Kota Padang Tahun 2012. Jurnal Kesehatan Andalas 3(2).

Mangkat, O., Mayulu, N., dan Kawengian, S.E.S. (2016). Gambaran pemberian makanan pendamping ASi anak usia 6-24 bulan di Desa Mopusi Kecamatan Lolayan Kabupaten
Bolaang Mongondow Induk. Jurnal eBiomedik (eBm). Vol. 4 No. 2.

PERSAGI. (2009). Kamus Gizi Pelengkap Kesehatan Keluarga. Jakarta : Kompas Media Nusantara.

Pratiwi, I. J. A. M.-A. D. D. (2010). Hubungan Jenis Asupan MP-ASI Dominan dengan Status Gizi Anak Usia6-24 Bulan. Surakarta: Fakultas Kedokteran Universitas Sebelas Maret.

Rahmadi, A. (16 April 2012). Pentingnya MP-ASI. (Online)

http://nutrisicare.wordpress.com/2012/04/16/pe ntingnya-mp-asi/, diakses 29 Januari 2016.

RISKESDAS. (2013). Badan Penelitian dan Pengembangan Kesehatan Kementerian Kesehatan RI tahun 2010. Jakarta

Ulfah, F. (2011). Hubungan Perilaku Ibu Tentang MP-ASI dengan Status Gizi pada Anak Usia 25-30 Bulan di Desa Ranah dan Penyasawan Kecamatan Kampar I tahun 2011. Skripsi Program Ilmu Kesehatan Masyarakat STIKes Hang Tuah Pekanbaru : Pekanbaru. Tidak diterbitkan. 